\title{
Periton Diyalizi Programında İzlenen Kronik Böbrek Yetersizlikli Çocuklarda Sol Ventrikül Geometrisinin Değerlendirilmesi
}

\author{
Assessment of Left Ventricular Geometry in Children with Chronic \\ Kidney Disease Undergoing Peritoneal Dialysis
}

\author{
Emine AZAK ${ }^{1}$, Ozan ÖZKAYA²
}

${ }^{1}$ Ankara Şehir Hastanesi, Çocuk Hastanesi, Çocuk Kardiyolojisi, Ankara, Türkiye

2istinye Üniversitesi Tıp Fakültesi, Bahçeşehir Hastanesi, Çocuk Nefroloji Bölümü, İstanbul, Türkiye

\begin{abstract}
Öz
Amaç: Kronik böbrek yetmezliği (KBY) olan çocuklarda kardiyovasküler morbidite artmıştır. Ancak kardiyak değişikliklerin hastalığın hangi evresinde ortaya tam olarak bilinmemektedir. Bu çalıșmada periton diyaliz programında izlenen son dönem böbrek yetmezliği olan çocuklarda sol ventrikül geometrisinin değerlendirilmesi amaçlanmıştır.

Gereç ve Yöntemler: Periton diyalizinde izlenen 20 KBY'li çocukta ekokardiyografik ve biyokimyasal veriler değerlendirildi. Sol ventrikül kitlesi ve rölatif duvar kalınlığı hesaplandı. Kontrol grup olarak 20 sağıkıı çocuk alındı.

Bulgular: Sol ventrikül kitle indeksi ve rölatif duvar kalınlı̆ı KBY grubunda kontrol grubuna göre anlamlı olarak yüksek bulundu (sirasıly $88.03 \pm 37.09 ; 41.16 \pm 12.52$ ve $0.62 \pm 0.12 ; 0.39 \pm 0.08$, $p>0.05$ ). Sol ventrikül kitle indeksi ile sistolik kan basıncı ve parathormon arasında anlamlı bir ilişki vardı (sırasıyla $r=0.428, p=0.03 ; r=-0.501, p=0.02$ ). KBY'li 17'sinde (\%85) çocukta anormal sol ventrikül geometrisi mevcuttu. Konsantrik hipertrofi, çalışmada en sık anomal sol ventrikül geometrisiydi. Periton diyalizi olan hastaların 9'unda (\%45) sol ventrikülde konsantrik hipertrofi izlendi. KBY'li çocuklarda

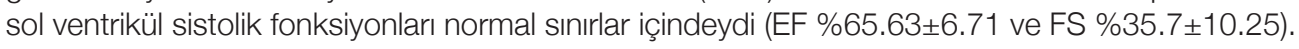

Sonuç: Sol ventrikül hipertrofisi (LVH) kronik böbrek yetmezliği olan çocuklarda ilerleyicidir. Kan basıncının ve hiperparatiroidizimin daha yakın kontrolü bu hastalarda LVH gelişimini önlemede önemli olabilir.

Anahtar Sözcükler: Ekokardiyografi, Periton diyalizi, Sol ventrikül geometrisi

\begin{abstract}
Objective: Cardiovascular morbidity seems increased in children with chronic renal failure, but the age and stage of disease when cardiac alterations become manifest are unknown. The aim of our study was aimed to evaluate the left ventricular geometry of children with chronic renal failure (CRF) undergoing peritoneal dialysis.

Material and Methods: Echocardiographic and biochemical data were evaluated in 20 children on peritoneal dialysis (PD). Left ventricular mass index and relative wall thickness was calculated. There were 20 healthy control.

Results: Left ventricular mass index and relative wall thickness were found significantly higher in CRF group compared to control group (respectively $88.03 \pm 37.09 ; 41.16 \pm 12.52$ and $0.62 \pm 0.12 ; 0.39 \pm 0.08, p>0.05$ ). There was significant correlation between left ventricular mass index and systolic blood pressures and parathormone (respectively $r=0.428$,
\end{abstract}

(1)

AZAKE : :0000-0002-7841-1331 OZZKAYA O : :0000-0002-0198-1221
Çıkar Çatışması / Conflict of Interest: Tüm yazarlar adına, ilgili yazar çıkar çatışması olmadığııı belirtir.

Etik Kurul Onayı / Ethics Committee Approval: Çalıșma Ondokuz Mayıs Üniversitesi Tıp Fakültesi Dekanlı̆ı Etik Kurul'u tarafından onaylandı (PYO. TIP.1901.09.051).

Yazarların katkısı / Contribution of the Authors: AZAK E: Araștırma ve/veya makalenin hipotezini veya fikrini olușturan, Sonuçlara ulașmak için planlama/ metodoloji belirleme, Araştırma/çalışmanın sorumluluğunu üstlenmek, ilerlemenin seyrini denetlemek, Hasta takibinde sorumluluk almak, ilgili biyolojik malzemelerin toplanması, veri yönetimi ve raporlama, deneylerin yürütülmesi, Sonuçların mantıksal olarak Yorumlanması ve sonuçlandıılması, Çalıșma için gerekli literatür taramasında sorumluluk almak, Çalıșmanın bütününün veya önemli bölümlerinin yazımında sorumluluk almak, Yazım ve dilbilgisi dıșnda bilimsel olarak gönderilmeden önce makaleyi gözden geçirme. ÖZZKAYA O: Araștırma ve/veya makalenin hipotezini veya fikrini oluşturan, Sonuçlara ulașmak için planlama/metodoloji belirleme, Araştırma/çalışmanın sorumluluğunu üstlenmek, ilerlemenin seyrini denetlemek, Hasta takibinde sorumluluk almak, ilgili biyolojik malzemelerin toplanması, veri yönetimi ve raporlama, deneylerin yürütülmesi, Sonuçların mantıksal olarak Yorumlanması ve sonuçlandırılması, Çalışma için gerekli literatür taramasında sorumluluk almak, Çalışmanın bütününün veya önemli bölümlerinin yazımında sorumluluk almak, Yazım ve dilbilgisi dışında bilimsel olarak gönderilmeden önce makaleyi gözden geçirme.

Atıf yazım şekli / How to cite : Azak E, Özkaya O. Periton Diyalizi Programında İzlenen Kronik Böbrek Yetersizlikli Çocuklarda Sol Ventrikül Geometrisinin Değerlendirilmesi. Türkiye Çocuk Hast Derg 2021;15:325-330.
Yazıșma Adresi / Correspondence Address:

Emine AZAK

Ankara Șehir Hastanesi, Çocuk Hastanesi,

Çocuk Kardiyolojis Kliniğii, Ankara, Türkiye

E-posta: azakemi@gmail.com
Geliş tarihi/ Received : :03.04.2021 Kabul tarihi / Accepted : 01.06.2021 Elektronik yayın tarihi : 18.06 .2021 Online published

DOI: 10.12956/tchd.907536 
$p=0.03 ; r=-0.501, p=0.02)$. An abnormal left ventricular geometric pattern was present in 17/20 (85\%) children with CRF. Concentric hypertrophy was the most common geometric pattern in the study. Nine (45\%) of patients with CRF had left ventricular concentric

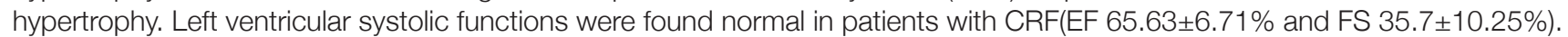

Conclusion: Left ventricular hypertrophy $(\mathrm{LVH})$ can be progresses in children with chronic renal failure. The strict control of blood pressure and hyperparathyroidism might be important in preventing the development of LVH in these patients.

Key words: Echocardiography, Peritoneal dialysis, Left ventricular geometry

\section{GiRiş}

Kardiyovasküler hastalıklar kronik böbrek yetersizliği (KBY) olan hastalarda morbidite ve mortalitenin önemli nedenlerindendir. Hastaların sıklıkla kardiyak fonksiyon bozuklukları nedeniyle hospitalize edildikleri ve hastanede kalıș sürelerinin uzadığı bilinmektedir. Bu nedenle KBY'nin her döneminde hastaların kardiyak fonksiyonlarının yakın izlemi ve komplikasyonların tedavisi prognoz açısından son derece önemlidir (1-3).

KBY'de kardiyovasküler sistemdeki değișiklikler hastalı̆ı̆ın erken dönemlerinden itibaren bașlar. Kardiyak fonksiyonların bozulması çeşitli faktörlerin etkisiyle gelişen karmaşık bir süreçtir. Bu süreçte kalbin ön yükü, ard yükü, kontraktilite ve kalp hızı gibi kardiyak performansı belirleyen tüm parametrelerin değişik derecelerde etkilendiği bilinmektedir. Bütün bu hemodinamik bozuklukların sonucunda KBY'li hastalarda değişik derecelerde sol ventrikül hipertrofisi, sol ventrikül dilatasyonu, sistolik ve diyastolik fonksiyon bozuklukları, aritmiler, kapak yetersizlikleri, iskemik değişiklikler ve perikardiyal efüzyon gelişir. Bu faktörlerin etkin bir diyaliz ve uygun medikal yaklașımla tedavi edilmesi, kardiyak fonksiyon bozukluklarını kısmen ortadan kaldırabilir. Bu nedenle kardiyovasküler sistem bulguları KBY'li hastalarda tedavinin etkinliğinin bir göstergesi olarak kabul edilir (2-6).

Çalışmalarda KBY vakalarının yaklaşık \%30 kadarında sol ventrikül ejeksiyon fraksiyonu (EF) normal bulunmasına rağmen kalp yetersizliği kliniğinin ortaya çıktığı saptanmıştır. Bu durum izole bozulmuş miyokardiyal relaksasyonuna bağlı kalp yetersizliği ile ilişkilidir (5-6).

$\mathrm{Bu}$ çalışmada periton diyalizi programında izlenen KBY'li çocuklarda sol ventrikül geometrisindeki değişikliklerin araştırıması amaçlandı.

\section{GEREÇ ve YÖNTEMLER}

Ondokuz Mayıs Üniversitesi Tıp Fakültesi Çocuk Nefroloji Bilim Dalı'nda periton diyalizi programında izlenen yașları 7-17 yıl arasında değișen toplam 20 olgu ve kontrol grubu olarak benzer yaș ve cins dağılımında kardiyak muayenesi normal olan 20 sağ|ıklı çocuk alındı. Tüm olguların elektrokardiyografi ve ekokardiyografi ile kardiyak incelemeleri yapıldı.

En az bir yıldır periton diyalizi proğramında izlenen KBY'li olgular araștırmaya dahil edildi. Hemodinamik önemli kalp kapak hastalı̆̆ı, kalp kası tutulumu yapan hastalık, doğuştan kalp hastalığı, aritmi öyküsü, kronik pulmoner ve karaciğer hastalığı, enfeksiyon hastalığı, troid fonksiyon bozukluğu ve diyabeti olan olgular çalışmaya kabul edilmedi.

Çalışma Ondokuz Mayıs Üniversitesi Tıp Fakültesi Dekanlığı Etik Kurul'u tarafından onaylandı (PYO.TIP.1901.09.051). Olguların ebeveynlerinden bilgilendirilmiş onam formu alındı.

Ekokardiyografik inceleme Doppler ekokardiyografi cihazı (GEVivid 7 system. Horton, Norway) ile 3.5 Mhz prob kullanilarak 4 boșluk ve parasternal uzun eksende yapıldı. Ekokardiyografik ölçümler birbirini takip eden üç siklusta yapılarak ortalamaları alındı. Olguların ekokardiyografik değerlendirmesi diyaliz uygulamasından hemen sonra hastalar kuru ağırlığında iken yapıldı.

M-mod ölçümler için parasternal uzun eksen görüntülerden, sol ventrikül diastol sonu çapı (LVIDd, mm), sol ventrikül sistol sonu çapı (LVIDs, mm), interventriküler septum diastol sonu kalınlığı (IVSTd, mm), interventriküler septum sistol sonu kalınlığı (IVSTs, $\mathrm{mm}$ ), sol ventrikül arka duvar diastol sonu kalınlığ (LVPWTd, mm), sol ventrikül arka duvar sistol sonu kalınlığı (LVPWTs, mm), sol ventrikül ejeksiyon fraksiyonu (EF,\%) ve kısalma fraksiyonu (SF,\%) hesaplandı. Tüm ölçümler vücut yüzey alanına (VYA) bölünerek standardize edildi.

Sol ventrikül kitlesi (SVK) Devereux formülüne göre, sol ventrikül kitle indeksi (SVKI) sol ventrikül kitlesinin vücut yüzey alanına (VYA) bölünmesiyle hesaplandı (7).

SVK $(\mathrm{gr})=0.8\left(1.04[\mathrm{LVIDd}+\mathrm{LVPWTd}+\mathrm{IVSTd}]^{3}-\left[\mathrm{LVIDd}^{3}\right)+\right.$ 0.6

SVKI $\left(\mathrm{gr} / \mathrm{m}^{2}\right)=$ Sol ventrikül kitlesi $/$ YA

Göreceli duvar kalınlığı (RWT, mm)=(2 xLVPWTd)/LVIDd formülü ile hesaplandı.

Sol ventrikül kitle indeksi ve göreceli duvar kalınlığına göre sol ventrikül geometrileri; normal geometri (SVKI normal, RWT normal), konsantrik remodelling (SVKI normal ve RWT artmış), konsantrik hipertrofi (SVKI ve RWT artmış) ve eksantrik hipertrofi (SVKI artmış, RWT normal) olarak değerlendirildi (8).

\section{İstatistiksel değerlendirme}

SPSS Statistics 18.0 (SPSS Inc., Chicago, IL, ABD) programı kullanıldı. Verilerin normal dağlımı Kolmogrov-Simirnov testi yapılarak belirlendi. Kesikli değişkenler sayı/yüzde, sürekli değișkenler ortalama \pm SD ve ortanca olarak verildi. Kesikli değişkenlerinin karşılaştııımasında Ki-kare testi, sürekli değişkenlerin karşılaştııımasında Mann-Whitney $U$ testi kullanıldı. Değişkenlerin birbirleri ile ilişkilerini belirlemede 
Spearman koerlasyon analizi kullanıldı. $p<0.05$ anlamllık sınırı kabul edildi.

\section{BULGULAR}

Olguların yaşı periton diyalizi grubunda $11.2 \pm 3.22$ yıl iken, kontrol grubun $11.61 \pm 2.59$ yıldı. Periton diyalizi grubunda olguların 12'si (\%60) kız, 8'i (\%40) erkek, kontrol grubunda 11'i kız (\%55), 9'u (\%45) erkekti. Periton diyalizi (PD) olgularının KBY etyolojileri değerlendirildiğinde 20 hastanın 6'sında (\%30) ürolojik nedenler, 3 'ünde (\%15) glomerulopati, 5 'inde (\%25) hipoplazidisplazi, 2'sinde (\%10) herediter nefropati ve 1 'inde (\%5) vaskülit saptandı. Üç (\%15) hastanın KBY nedeni bilinmiyordu. Olguların KBY tanısı ile izlem süreleri $5.65 \pm 2.69$ yıl (ortanca: 5.2 yıl) arasındaydı. Hasta ve kontrol grup arasında yaş, cinsiyet, vücut ağırlığı, vücut yüzey alanı (VYA) ve vücut kitle indeksi (VKI) açısından istatiksel olarak anlamlı fark tespit edilmedi (Tablo I).

Kreatin klirensi preriton diyaliz proğramında izlenen hastalarda $26.3 \pm 13.7 \mathrm{ml} / \mathrm{dk}$ (otanca:17) olarak saptandı. Gruplar arasında trombosit, albümin, kalsiyum ve fosfor değerleri arasında istatiksel olarak anlamlı fark saptanmadı. Periton diyalizi grubunda kontrol gruba göre hemoglobin ve hematokrit değerleri daha düşük iken, ferritin değeri daha yüksekti. Tablo Il'de olguların laboratuvar bulguları verilmiştir.

Periton diyaliz grubunda QRS aksının 9 hastada normal olduğu, bir hastada sol aksın olduğu belirlendi. PR intervali tüm hastalarda 0.12-0.20 msn arasında değişiyordu. Ortalama QTc intervali $438 \pm 33 \mathrm{msn}, \mathrm{QRS}$ süresinin ise tüm olgularda yaşa göre normal sınırlar içinde olduğu görüldü. Hiçbir olguda ritm bozukluğu saptanmadı. EKG'de anormal sol ventrikül geometrisi olan 17 hastanın yalnızca 6'sında (\%37.5) sol ventrikül hipertrofisi bulgularının olduğu görüldü.

Ekokardiyografik incelemelerinde; 15 (\%75) olguda hafif-orta mitral kapak yetersizliği, 8 (\%40) olguda hafif-orta aort kapak yetersizliği, 9 (\%45) olguda hafif triküspit yetersizliği saptandı. Altı olguda (\%30) minimal perikardiyal efüzyon saptandı. Periton diyaliz grubunda kontrol grubuna göre sol ventrikül ve interventriküler septumunun sistol ve diyastol kalınlıklarının arttığı, sol ventrikül kitle indeksinin anlamlı yüksek olduğu saptandı. Ayrıca sol ventrikülün sistol ve diyastol sonu çapları hasta grubunda daha yüksekti. Sol ventrikül sistolik fonksiyonları değerlendirildiğinde periton diyaliz grubunda EF ve FS değerleri

Tablo I: Periton diyalizi ve kontrol grubun demografik özellikleri.

\begin{tabular}{|c|c|c|c|}
\hline & Periton Diyalizi (n:20) & Kontrol (n:20) & p \\
\hline Yaş (yıl) & $11.23 \pm 3.22(11.21)$ & $11.61 \pm 2.59(11.31)$ & 0.120 \\
\hline Cinsiyet(kız/erkek)* & $12(\% 60) / 8(\% 40)$ & $11(\% 55) / 9(\% 45)$ & 0.340 \\
\hline Kilo (kg) & $36.19 \pm 12.14(29.51)$ & $38.51 \pm 10.95(36.52)$ & 0.090 \\
\hline VYA $\left(m^{2}\right)$ & $0.98 \pm 0.26(1.17)$ & $1.24 \pm 0.22(1.22)$ & 0.110 \\
\hline VKi (kg/m²) & $17.46 \pm 3.81(16.11)$ & $18.11 \pm 2.56(17.65)$ & 0.080 \\
\hline SKB (mmHg) & $138.21 \pm 14.87$ & $118.33 \pm 15.21$ & 0.010 \\
\hline DKB (mmHg) & $93.12 \pm 11.61$ & $76.41 \pm 10.75$ & 0.010 \\
\hline
\end{tabular}

*Sayı ve \% olarak ifade edilmiştir. VYA: Vücut yüzey alanı; VKI: Vücut kitle indeksi; SKB: sistolik kan basıncl; DKB: diyastolik kan basıncı

Tablo II: Periton diyalizi ve kontrol grubun laboratuvar bulguları.

\begin{tabular}{|c|c|c|c|}
\hline & Periton diyalizi $(n=20)$ & Kontrol $(n=20)$ & $p$ \\
\hline $\mathrm{CrCl}(\mathrm{ml} / \mathrm{dk})$ & $13.72 \pm 26.31(6.72)$ & - & - \\
\hline BUN (mg/dL) & $65.99 \pm 33.38(58.85)$ & $19.73 \pm 3.78(18.21)$ & 0.001 \\
\hline $\operatorname{Kreatinin}(\mathrm{mg} / \mathrm{dL})$ & $7.21 \pm 2.63(7.64)$ & $0.69 \pm 0.15(0.68)$ & 0.001 \\
\hline $\mathrm{Hgb}(\mathrm{gr} / \mathrm{dl})$ & $10.11 \pm 2.24(10.12)$ & $11.92 \pm 0.73(11.85)$ & 0.001 \\
\hline Htc (\%) & $29.75 \pm 6.53(29.12)$ & $36.16 \pm 2.27(36.21)$ & 0.001 \\
\hline PLT $\left(/ \mathrm{mm}^{3}\right)$ & $282.12 \pm 78.48(238)$ & $288.84 \pm 89.31(241)$ & 0.114 \\
\hline Ferritin (mL/ng) & $485.43 \pm 350.25(366)$ & $51.12 \pm 18.97(48.51)$ & 0.001 \\
\hline Albümin(mg/dL) & $3.9 \pm 0.59(4)$ & $4.06 \pm 0.95(4.25)$ & 0.242 \\
\hline $\mathrm{Ca}(\mathrm{mg} / \mathrm{dL})$ & $9.37 \pm 0.87(9.6)$ & $9.17 \pm 0.552(9.17)$ & 0.102 \\
\hline$P$ (mg/dL) & $4.89 \pm 1.38(4.91)$ & $5.01 \pm 0.96(5.21)$ & 0.698 \\
\hline Ca xP & $45.57 \pm 12.71(48.53)$ & $46.82 \pm 10.42(49.14)$ & 0.779 \\
\hline PTH $(p g / m L)$ & $618.37 \pm 522.31(395.81)$ & - & - \\
\hline
\end{tabular}

* Veriler ortalama \pm standart sapma (min-mak) (ortanca) olarak verilmiştir. CrCl: Kreatinin Klirensi; BUN: Kan üre azotu; Hgb: Hemoglobin; Htc: Hematokrit; PLT: Trombosit 
Tablo III. Periton diyalizi ve kontrol grubun M-Mode Ekokardiyografi bulguları.

\begin{tabular}{l|ccc}
\hline & Periton Diyalizi & Kontrol & p \\
\hline LVIDs/VYA & $41.11 \pm 7.26(39.41)$ & $35.16 \pm 3.91(35.1)$ & 0.01 \\
\hline LVIDd/VYA & $38.63 \pm 9.55(37.78)$ & $35.16 \pm 3.59(35.12)$ & 0.01 \\
\hline LVPWTs/VYA & $14.17 \pm 2.38(14.23)$ & $9.2 \pm 1.69(9.22)$ & 0.001 \\
\hline LVPWTd/VYA & $11.74 \pm 2.18(11.91)$ & $6.93 \pm 0.85(6.87)$ & 0.001 \\
\hline IVSTs/VYA & $14.51 \pm 2.31(14.9)$ & $9.74 \pm 0.59(9.81)$ & 0.001 \\
\hline IVSTd/VYA & $12.13 . \pm 2.46(12.16)$ & $0.69 \pm 0.77(7.85)$ & 0.001 \\
\hline RWT & $0.62 \pm 0.12(0.59)$ & $41.16 \pm 12.52(37.51)$ \\
\hline SVKi & $88.03 \pm 37.09(77.6)$ & $68.99 \pm 4.553(70.81)$ & 0.001 \\
\hline EF (\%) & $66.23 \pm 6.71(65.3)$ & $37.31 \pm 2.98(39.13)$ \\
\hline FS (\%) & $35.7 \pm 10.25(36.6)$ & 0.133 \\
\hline
\end{tabular}

* Veriler ortalama \pm standart sapma (ortanca) olarak verilmiştir. Sol ventrikül sistol sonu çapı (LVIDs, mm), sol ventrikül diaystol sonu çapı (LVIDd, mm), sol ventrikül arka duvar sistol sonu kalınlığı (LVPWTs, mm), sol ventrikül arka duvar diyastol sonu kalınlığ (LVPWTd, mm), interventriküler septum sistol sonu kalınığı IVSTS (mm), interventriküler septum diyastol sonu kalınlığı (IVSTd, mm), sol ventrikül ejeksiyon fraksiyonu (EF, \%), sol ventrikül kısalma fraksiyonu (FS, \%), sol ventrikül kitle indeksi (SVKI, gr/m²), sol ventrikül rölatif duvar kalınlığı (RWT).Tüm ölçümler vücut yüzey alanına (VYA) bölünerek standardize edildi.

Tablo IV: Periton Diyalizi tedavisi grubunda kardiyak geometri.

\begin{tabular}{l|c}
\hline & Periton Diyaliz tedavisi (\%) \\
\hline Normal & $3(15)$ \\
Konsantrik remodelling & $4(20)$ \\
Konsantrik hipertrofi & $9(45)$ \\
Eksantrik hipertrofi & $4(20)$ \\
\hline
\end{tabular}

kontrol grubuna göre daha düşük olmasına rağmen gruplar arasında anlamlı fark saptanmadı. Periton diyaliz gurubunda genel olarak sol ventrikül sistolik fonksiyonlarının normal olduğu görüldü. Tablo Ill'de olguların ekokardiyografi bulguları özetlenmiștir.

Periton diyaliz grubundaki olguların sol ventrikül geometrilerine baktı̆ı̆ımızda; 9'unda (\%45) sol ventrikülde konsantrik hipertrofi, 4'ünde (\%20) eksantrik hipertrofi, 4'ünde (\%20) konsantrik remodelling (simetrik yeniden yapılanma) olduğu izlendi. Üç (\%15) olgunun ise sol ventrikül geometrisinin normal olduğu görüldü (Tablo IV).

Çalışmamızda SVKI ile SKB değerleri ve parathormon düzeyi arasında anlamlı ilişki saptandı (sırasıyla $r=0.428, p=0.03$; $r=-$ $0.501, p=0.02$ ).

\section{TARTIȘMA}

Kronik böbrek yetersizlikli genç erişkin ve çocuklarda kardiyovasküler sistem ile ilgili patolojiler mortalite ve morbidite önemli nedenlerindendir (1-4). KBY'li erișkin olgularda sol ventrikül fonksiyon bozuklukları, sol ventrikül hipertrofisi, aritmiler, arteriyel sertlik ve koroner kalsifikasyonlar kardiyak morbidite ve mortalitenin bağımsız göstergeleri olarak kabul edilmiștir (1,5-9). Diyaliz yöntemleri ve konservatif tedavi alanlarındaki gelişmelere rağmen bu gerçek değiştirilememiştir. KBY'li çocuklarda kardiyovasküler sisteme ait risk faktörleri ile ilgili bilgiler yeterli değildir. Bu olgularda diyaliz tedavisinde geçen sürenin mümkün olduğunca kısa tutulması ve uygun vakalarda transplantasyonun daha fazla düșünülmesi ortak görüș olarak kabul edilmiştir (1,9-12).

KBY'li olgularda kardiyovasküler hasar diyaliz öncesi dönemde bașlar. Diyalizde gözlenen komplikasyonlar süregiden bir olayın sonuçlarıdır. Diyaliz tedavisinde izlenen çocukların \%51'inde ölüm sebebi kardiyovasküler hastalıklarıdır $(9,10)$. Bu nedenle KBY'li çocuklarda kardiyovasküler sistem hızlı ve invazif olmayan tanı yöntemleri ile değerlendirilmelidir.

Çalışmalarda; KBY'li erişkinlerde sistolik disfonksiyonun oldukça yüksek prevalansa sahip olduğu, bu olgulardaki erken kalp yetersizliğinin azalmış sağ kalımı gösterdiği bildirilmiștir (11-14). Kronik böbrek yetersizlikli çocuklarda sıklikla sol ventrikül sistolik fonksiyonları korunurken, kardiyak fonksiyon anormalliğinin bașlangıç bulgusu olan diyastolik fonksiyon bozukluğu mevcuttur $(11,14-16)$. Yapılımış bir çalışmada KBY'li olgularda sol ventrikül hipertrofisine rağmen sistolik fonksiyonlar normal olarak bulunmuştur (15). Çalışmamızda sol ventrikül hipertrofisi saptadığımı olgularda dahil çalışma grubunda sol ventrikül sistolik fonksiyonları normal sınılar içerisindeydi. Ancak çalıșmamız retrospektif olması ve amacımızın sadece sol ventrikül geometrisini değerlendirmek olduğu için olgularımızda sol ventrikül diyastolik fonksiyonlarıı değerlendiremedik. Erișkin hastalara göre sol ventrikül sistolik fonksiyon bozukluğunu daha az görmemizin nedenini olgularımızın çocukluk yaş grubunda olması, son dönem böbrek yetmezliğinde olan olgularımızın nispeten iyi kontrollu olması ve erișkin yașta görülen sekonder nedenlerin olmaması ile ilișkili olabileceğini düșündük.

Çalışmamızda sol ventrikül sistol ve diastol sonu çaplarının kontrol grubuna göre daha yüksek olduğunu saptadık. 
Araştırmalarda KBY'li çocuklarda prediyaliz dönemde SVKI'indeki artışa ilaveten sol ventrikül diyastol sonu boyutunda ve arka duvar kalınlığında anormallik olduğu görülmüştür (10,17-22). Ekokardiyografik incelemelerimizi hastalar kuru ağılıklarında iken yapıımış olmasından dolayı sonuçlarımızın güvenilir olduğunu düşünmekteyiz.

Kronik böbrek yetersizlikli olgularda kardiyovasküler hastalık gelişiminde, birincisi mekanik veya hemodinamik yüklenme nedeni ile oluşan sol ventrikül hipertrofisi, ikincisi ateroskleroz ve kalsifikasyon sonucunda gelişen vasküler hastalıklar olmak üzere paralel iki süreç vardır (18-20). Genel olarak konsantrik hipertrofi basınç fazlalığı eksantrik hipertrofi ise volüm fazlalığı ile ilişkilidir. KBY'li olgularda sol ventrikülde morfolojik ve fonksiyonel değişikliklerin en önemli nedeni hipertansiyondur (20-24). Kronik diyaliz tedavisi alan olgularda aneminin düzeltilmesinin SVKI'nde azalma sağladığı gösterilmiştir (18).

Çalışmamızda SVKI, sol ventrikül arka duvar ve septum kalınlıklarının periton diyaliz grubunda kontrol grubuna göre daha yüksek olduğu görüldü. KBY'li çocuklarda sol ventrikül hipertrofisinin böbrek yetersizliğinin hafif ve orta olduğu dönemde bașladığı böbrek fonksiyonları azaldıkça ilerleme gösterdiği bildirilmiştir (18-23). KBY'li 31 çocuğun 2 yıl takip edildiği prospektif bir çalışmada, başlangıçta \%19 bulunan sol ventrikül hipertrofi oranın takip sonunda \%39'a yükseldiği bildirilmiştir (21). Çalışmamızda periton diyalizi programında olan olguların SVKI'nin artmış olduğunu ve konsantrik hipertrofinin periton diyalizi yapılan olgularda en çok görülen kardiyak geometri olduğunu saptadık. Bu sonuçlar KBY'li olgularda sol ventrikül değişikliklerinin prediyaliz dönemde başlayabileceğini ve hasarlanmanın diyalize rağmen devam edebileceğini göstermektedir.

Bazı çalışmalarda prediyaliz dönemindeki çocuklarda konsantrik hipertrofinin, diyaliz programındaki çocuklarda ise sıklıkla eksantrik sol ventrikül hipertrofisinin görüldüğü bildirilmiştir $(3,17,25,26)$. Biz periton diyalizindeki çocuklarda sol ventrikülde en çok konsantrrik hipertrofi olduğunu gördük.

Hipertansiyon KBY'li hastalarda sol ventrikül hipertrofisi ve fonksiyon bozuklukları için önemli bir risk faktörüdür. Kronik diyaliz tedavisi alan çocuklarda SVH ile kan basıncı arasında anlamlı bir ilişkinin olduğu saptanmıştır (18-20). Çocukluk çağı prediyaliz ve diyaliz dönemindeki olgularda yapılmış bazı çalş̧malarda SVKI ile kan basıncı arasında anlamlı ilişki saptanmamıştır $(3,9,22)$. Hipertansiyonun KBY'li çocuklarda erken dönemde SVH patogenezinde çok küçük bir rolü olduğunu bildiren çalışmalarda bu durumun hastaların antihipertansif kullanmalarına ve kan basınçlarının normal düzeylerde seyretmesine bağlı olduğu bildirilmiştir. Ancak, KBY'li hastalarda özellikle gece artan SKB değerleri ile SVKI arasında anlamlı ilişki olduğu bildirilmiştir $(17,19,23,24)$. Çalışmamızda literatür ile uyumlu olarak özellikle SKB değerleri ile SVKI arasındaki ilişkinin daha önemli olduğunu gördük. Basınç yükü artmış KBY'li olgularda sol ventrikülde daha çok konsantrik konsantrik hipertrofinin görüleceğini düşünmekteyiz.
KBY'ne bağlı gelișen hiperfosfatemi, artmış kalsiyum-fosfor çarpımı (CaxP) ve sekonder hiperparatiroidizm üremiye bağlı kardiyovasküler risk faktörleri arasında önemli bir yer tutmaktadır. KBY'li çocuklarda sol ventrikülde hipertrofi tespit edilen hastalarda PTH düzeyinin anlamlı ölçüde yüksek olduğu bulunmuştur $(26,27)$. Çalışmamızda PTH düzeyi ile sol ventrikül kitlesi ve rölatif duvar kalınlıkları arasında anlamlı ilişki olduğu görülmüştür. Bulgular KBY'li çocuklarda hiperparatiroidizmin SVH gelişiminde risk faktörü olduğunu düşündürebilir.

Çalışmamızın kısıtlıı̆ı̆nı, sadece son dönem böbrek yetersizliği olan çocukların alınmış olması ve hastalığın evrelerine göre karşılaştırma yapılamamış olması olarak kabul edilebilir.

\section{SONUÇ}

Erişkinlerin aksine periton diyalizi programında izlenen KBY'li çocuklarda sistolik fonksiyonlar çoğunlukla korunmuştur. Periton diyalizi yapılan KBY'li çocuklarda sol ventrikül hipertrofisi ve sol ventrikül geometrisinde bozulma hastalığın erken evrelerinde başlayabilir. Bu olgularda çocukluk çağından itibaren kardiyovasküler sistem komplikasyonları ön planda olduğundan dolayı kardiyak muayeneleri düzenli ve dikkatli olarak yapılmalıdır. Özellikle üremi ile ilişkili kardiyovasküler risk faktörleri yakından takip edilmeli ve erken dönemde tedavi uygulanmalıdır.

\section{KAYNAKLAR}

1. Groothoff JW, Lilien MR, van der Kar NCAJ, Wolff ED, Davin JC. Cardiovascular disease as a late complication of end-stage renal disease in children. Pediatr Nephrol 2005; 20: 374-79.

2. Weaver DJ, Mitsnefes M.Cardiovascular Disease in Children and Adolescents With Chronic Kidney Disease. Semin Nephrol 2018; 38:559-69.

3. El-Gamasy MA, Mawlana WH. Risk factors and prevalence of cardiac diseases in Egyptian pediatric patients with end-stage renal disease on regular hemodialysis. Saudi J Kidney Dis Transpl 2019; 30:53-61.

4. Groothoff JW. Long-term outcomes of children with end-stage renal disease. Pediatr Nephrol 2005; 20:849-53.

5. Arcari L, Ciavarella GM, Altieri S, Limite LR, Russo D, Luciani M, et al. Longitudinal changes of left and right cardiac structure and function in patients with end-stage renal disease on replacement therapy. Eur J Intern Med 2020; 78:95-100.

6. Mitsnefes MM, Daniels SR, Schwartz SA, Khoury P, Meyer RA, Strife CF. Severe left ventricular hypertrophy in pediatric dialysis: prevalance and predictors. Pediatr Nephrol 2000; 14:898-902.

7. Devereux RB, Alonso DR, Lutas EM, Gottlieb GJ, Campo E, Sachs I, et al. Echocardiographic assessment of left ventricular hypertrophy: Comparison to necropsy findings. Am J Cardiol 1986; 57: 450-58.

8. Malikenas A, Cerniauskiene V, Jakutovic M, Jankauskiene A. Left ventricular geometry in children with chronic renal failure. Medicina (Kaunas) 2005; 41 Suppl 1:5-11.

9. Parekh RS, Carrol CE,Wolfe RA, Port FK. Cardiovascular mortality in children and young adults with end-stage kidney disease. J Pediatr 2002; 141:191-7. 
10. Scavarda VT, Pinheiro AC, Costa SD, de Andrade ZM, Carvalhaes JT, Campos O, et al. Carvalho AC, Moises VA.Children with chronic renal disease undergoing dialysis or conservative treatment differences in structural and functional echocardiographic parameters. Echocardiography 2014; 31:1131-7.

11. Schoenmaker NJ, Kuipers IM, van der Lee JH, Tromp WF, van Dyck M, Gewillig M, et al. Diastolic dysfunction measured by tissue Doppler imaging in children with end-stage renal disease: a report of the RICH-Q study. Cardiol Young 2014; 24:236-44.

12. Goicoechea M, Garcia de Vinuesa S, Gomez-Campdera F, Luno J. Predictive cardiovascular risk factors in patients with chronic kidney disease. Kidney Int 2005; 67(Suppl 93): 35-8.

13. Mitsnefes MM. Cardiovascular complications of pediatric chronic kidney disease. Pediatr Nephrol 2008; 23:27-39.

14. Hayashi SY, Rohani M, Lindholm B, Brodin LA, Lind B, Barany P et al. Left ventricular function in patients with chronic kidney disease evaluated by colour tissue Doppler velocity imaging. Nephrol Dial Transplant 2006; 21:125-32.

15. Dogan CS, Akman S, Simsek A, Ozdem S, Comak E, Gokceoglu AU, et al. Assessment of left ventricular function by tissue Doppler echocardiography in pediatric chronic kidney disease. Ren Fail 2015; 37:1094-9.

16. Atalay S, Ekim M, Tutar HE, Kocak G, Bakkaloglu S, Tümer N. Systolic and diastolic function in children with chronic renal failure. Pediatr Int 2002; 44:18-23.

17. Mitsnefes MM, Daniels SR, Schwartz SM, Khoury P, Strife CF. Changes in left ventricular mass in children and adolescents during chronic dialysis. Pediatr Nephrol 2001;16:318-23.

18. Levin A, Thompson CR, Ethier J, Carlisle EJ, Tobe S, Mendelssohn $D$, et al. Left ventricular mass index increase in early renal disease: Impact of decline in hemoglobin. Am J Kidney Dis 1999; 34:12534.
19. Bircan Z,Duzova A,Çakar N,Bayazıt AK, Elhan A, Tutar E, et al. Predictors of left ventricular hypertrophy in children on choronic peritoneal dialysis. Pediatr Nephrol 2010; 25:1311-8.

20. Melhem N, Savis A, Wheatley A, Copeman H, Willmott K, Reid CJD, et al. Improved blood pressure and left ventricular remodelling in children on chronic intermittent haemodialysis: a longitudinal study. Pediatr Nephrol 2019; 34:1811-20.

21. Mitsnefes MM, Kimball TR, Kartal J, Witt SA, Glascock BJ, Khoury $\mathrm{PR}$, et al. Progression of left ventricular hypertrophy in children with early chronic kidney disease: 2-year follow-up study. J Pediatr 2006; 149:671-5.

22. Mitsnefes MM, Daniels SR, Schwartz SA, Khoury P, Meyer RA, Strife CF. Severe left ventricular hypertrophy in pediatric dialysis: prevalance and predictors. Pediatr Nephrol 2000; 14:898-902.

23. Shamszad P, Slesnick TC, Smith EO, Taylor MD, Feig DI.Association between left ventricular mass index and cardiac function in pediatric dialysis patients. Pediatr Nephrol 2012; 27:835-41.

24. Kobayashi D, Patel SR, Mattoo TK, Valentini RP, Aggarwal S.The impact of change in volume and left-ventricular hypertrophy on leftventricular mechanical dyssynchrony in children with end-stage renal disease. Pediatr Cardiol 2012; 33:1124-30.

25. Bakkaloglu S, Borzych D, Ha S, Serdaroglu E, Büscher R, Salas P. Cardiac Geometry in Children Receiving Chronic Peritoneal Dialysis: Findings from the International Pediatric Peritoneal Dialysis Network (IPPN) Registry. Clin J Am Soc Nephrol 2011; 6:1926-33.

26. Mitsnefes MM, Kimball TR, Kartal J, Witt SA, Glascock BJ, Khoury $\mathrm{PR}$, et al. Cardiac and vascular adaptation in pediatric patients with chronic kidney disease: role of calcium-phosphorus metabolism. J Am Soc Nephrol 2005;16:2796-803. 